BöLCSKEI-FARKAS-SLíz eds., Magyar és nemzetközi névtani terminológia. Hungarian and International Onomastic Terminology. Uppsala-Budapest: International Council of Onomastic Sciences - Magyar Nyelvtudományi Társaság, 2017. 65-84. DOI: $10.26546 / 5061110.9$

\title{
Terminological studies in International and Hungarian Onomastics
}

1. Introduction. The paper examines the history of terminological studies in onomastics, how its terminology was formed through the work of scholars, and the results of these studies. The first section of the paper offers an account of international terminological work in onomastics. These points review the various glossaries of onomastic terminology (point 2) as well as the major terminological projects (point 3 ) in the field of onomastic studies. The more voluminous second part of the paper provides a similar overview of Hungarian work processes in the terminology of onomastics. It enumerates initiatives that aimed to create a comprehensive and organised terminology for Hungarian onomastics (point 4) while bringing certain Hungarian studies on terminological questions to light (point 5). The final section (point 6) of the paper draws parallels and illuminates connections between native language terminologies (in this case Hungarian) and international terminological work processes.

2. International studies on onomastic terminology. The work of several scholars from a variety of countries has led to the publication of several mono- and multilingual term lists and glossaries. A brief summary of these publications is provided below.

2.1. German and Slavic onomastics pioneered organised terminological work. The first glossaries of terms were published in German (WITKOWSKI 1964), and on the terminology of certain Slavic languages (Ukrainian: NIMCHUK 1966; Sorbian [or Lusatian]: PETR 1969; later, Russian: PODOL'SKAJA 1978 and 1988). Through the international cooperation of researchers, and to ease joint projects, comparative lists of German and Slavic terminologies were compiled. The first was Základní soustava a terminologie slovanské onomastiky (known in German as Grundsystem und Terminologie der slawischen Onomastik) published in 1973 (SvOBODA et al. 1973), which was followed by Osnoven sistem i terminologija na slovenskata onomastika (known in other languages as Osnovnaja sistema i terminologija slavjanskoj onomastiki. Grundsystem und Terminologie der slawischen Onomastik) a decade later (BEZLAJ et al. 1983). A newer German glossary of terms has since been completed (WALTHER 1998). Similar glossaries have also been published in several Slavic languages. (E.g. in Ukrainian as an in-print terminological dictionary: BUCHKO-TKACHOVA 2012; in Polish, as a digital term list: GAŁKOWSKI 2012. For a collection of several Slavic languages see RZETELSKA-FELESZKO et al. eds. 2002-2003. 2: 567-602. Further Slavic glossaries are currently under production.)

Onomasticians from Northern Europe have also compiled glossaries of onomastic terms in their native languages (KIVINIEMI et al. 1974, SCHMIDT 1981). As did speakers of the major Uralic languages except for Hungarian: the Finnish terminology was 
published together with the Swedish (in KIVINIEMI et al. 1974), followed later by the Estonian (HENNO-PÄLL 2003).

Glossaries on the (American) English (SMITH 1967, RoOM 1996), and (Canadian) French (DORION-POIRIER 1975) terminologies of onomastics have also been published. However, similar works on onomastic terminology are yet to be published in many major languages, for example Italian (cf. GAŁKOWSKI 2010; but see the Italian-Hungarian bilingual glossary of FÁBIÁN 2001, mentioned in more detail below).

The importance of the glossaries compiled by the United Nations Group of Experts on Geographical Names (UNGEGN) and the International Council of Onomastic Sciences (ICOS) must be stressed as these are intended for international use. (The two glossaries are examined in detail below.)

2.2. Many terms that were incorporated in term lists and glossaries of onomastic terminology have become accepted norms in their respective languages over the past decades. However, there is notable demand, and intent, for the preparation of newer glossaries, as interest in the theoretic and practical problems of onomastic terminology has not dwindled. For example, the Slovak Onomastic Commission of the L. Štur Linguistic Institute of the Slovak Academy of Sciences has begun work on a systematic digital database of onomastic terminology with international cooperation. This database will provide several types of information regarding a certain term, including its equivalents in other languages. The need for a revised and augmented version of the multilingual Osnoven sistem $i$ terminologija na slovenskata onomastika (German-Slavic) dictionary (BEZLAJ et al. 1983) was also stressed a few years ago (cf. HARVALÍK 2007).

Recent synthetic works in national or international onomastics regularly approach the difficulties of onomastic terminology in some form. Either as recurring sections of successive thematic chapters (e.g. BRENDLER-BRENDLER Hrsg. 2004), as separate chapters (e.g. WITKOWSKI 1995, KALETA 1998), or a combination of these two methods (e.g. MARCATO 2009: 10-13 and passim), or as terminological appendices to the volumes (RZETELSKA-FELESZKO et al. eds. 2002-2003. 1: 81-94, 2: 567-602).

Interest in the subject is also indicated by how separate terminological sessions were added to three of the international triennial onomastic congresses (Pisa, 2005; Toronto, 2008; Barcelona, 2011) organised by the ICOS. It is also at these conferences that the ICOS Terminological Group holds its meetings.

The general, theoretic and methodological aspects of national or international onomastic terminology have been examined and re-examined in a large number of studies in past years. A similar number of papers have reviewed single questions, or single terms in great detail. (For the most relevant literature on the subject see the Lists of Key Onomastic Terms, published on the website of the ICOS.)

3. International work processes in onomastic terminology. Cooperation between scholars over political and lingual borders - especially more organised initiatives - have naturally drawn attention to the problems of onomastic terminology and the questions faced by any effort to harmonise it. This development has been governed by a series of practical decisions, initiatives and work on an international scale. 
3.1. Following the first conference on Slavic onomastics, held in 1959, the Commission of Slavic Onomastics of the International Committee of Slavists was formed. One of the four subcommittees created was the Terminological Subcommittee (WITKOWSKI 1995: 290). In cooperation with the Institute for Slavic Studies of the German Academy of Sciences it was this subcommittee that compiled the first glossary of onomastic terminology - containing ca. 600 terms - mentioned above (WITKOWSKI 1964). The committee also played an important role in later terminological research (for more on the Slavic terminology of onomastics see BAUKO 2015c: 254-256).

In Northern-European countries the NORNA - which was founded in 1979 and oversees the onomastic cooperation of Northern-European countries - also provided a good example of the importance of onomastic terminology. The first symposium organised by the NORNA was centred around the problems of onomastic terminology and the topic also resurfaced at later symposiums (GYÖRFFY 2007: 250).

3.2. In 1959 the United Nations created - under a different name at the time - the United Nations Group of Experts on Geographical Names (UNGEGN). The UNGEGN first published a glossary, containing the terms used in geographical names standardization in 1984, of which a reviewed version was released in 1987. The document was published in the six official languages of the UN. However, due to the deficiencies of the original glossary calls for the formation of a terminological working group surfaced by 1989. The resulting revised version of the glossary of terms, written under the direction of NAFTALI KADMON, contains nearly 400 entries connected to present day practices in geographical names standardization, and was also published in the six official languages of the organization in 2002 (Glossary of Terms for the Standarization of Geographical Names). The latter document has since been augmented by an Addendum, and has also been translated to other languages. The working group is tasked with the continuous maintenance and revision of the glossary. (For more on this subject see BÖLCSKEI 2017, in current volume. The cited documents are retrievable from the UNGEGN website.)

The international standardization of geographical names is a process in which several international organisations are involved, and naturally has many terminological aspects. An example of this is the standardization of undersea feature names. The document containing the defining principles and guides to this has been published by the International Hydrographic Organization in several editions and languages (cf. MÁRTON 2012: 184-192).

3.3. At the 2002 international onomastic congress in Uppsala MiLAN HARVALíK proposed the creation of a terminology workgroup within the International Council of Onomastic Sciences (cf. HARVALÍK 2005). The Terminology Group was formed in 2004 and compiled a basic term list containing definitions and examples through the cooperation of scholars from different countries and schools of onomastics. The glossary was published online in the three official languages of the ICOS: English (the original procedural language), German and French. The initial lists were first presented at the 2005 ICOS congress in Pisa, and following further work, a revised version was completed for the 2011 congress in Barcelona. The present lists contain the definitions of about 70 items (Lists of Key Onomastic Terms). The glossaries are retrievable from the ICOS 
website. (For more on this subject see HARVALíK 2014: 21-22, and BÖLCSKEI 2017, in current volume.)

The ICOS Terminology Group aimed to cooperate with a wide range of onomasticians. Following its creation, it approached a number of scholars from different countries with a short questionnaire regarding the general problems of the field and published their answers, as well as the general conclusions drawn (HARVALÍK-CAFFARELLI 2007). The survey illustrated how scholars of every language face a series of - in part similar, in part different - questions and difficulties within onomastic terminology. Following the completion of the above mentioned glossary the Terminology Group has broadened its goals and increased its subgroups. The aim of these is to make the glossary accessible to further languages and cultures through translation, and also to examine the terminology of the various fields of onomastics in more detail.

3.4. The members of the ICOS and the UNGEGN versed in the terminological questions of onomastics formed a joint terminological committee following an agreement at the Toronto congress of the ICOS in 2008. The respective glossaries of the two organisations - as is to be expected - differ in certain regards, however a number of these differences could be lessened through cooperation. (In more detail see NYSTRÖM 2014, cf. also VASILEVA 2014.) The organised collaboration of these two international organisations - which is aided by several personal connections - can only be seen as profitable for all concerned parties.

3.5. There have been few examples of either the UNGEGN or the ICOS glossaries of terms being translated. The Hungarian versions of these glossaries are published in the present volume, in-print and digitally.

4. Endeavours for the comprehensive organisation and publication of the Hungarian terminology of onomastics. A number of sporadic papers have discussed the characteristics of, or certain terms of Hungarian onomastic terminology in the past. However, only in the 1970s - in one of the most dynamic periods of Hungarian onomastics - did an in-depth and concise debate begin on its terminology. The initiative - like so many others - was spearheaded by MIHÁLY HAJDÚ, who later became the leading organisational figure of Hungarian onomastic studies. (See his academic memoir: HAJDÚ 2010: $24-26$.

4.1. The opening statement of this initiative was written in 1974 (Introduction to a Debate on Onomastic Terms; HAJDÚ 1974a) and distributed as a copied manuscript. Its content was discussed at a meeting of concerned scholars while others submitted their opinions to the author in writing. Based on these recommendations a new version was compiled in which changes to content and style were made. (This was unavoidable as the original document had been written to open the debate.) The revised document (HAJDÚ 1974b) was later submitted to the - then still active - Onomastic Committee of the Hungarian Academy of Sciences.

The main principles of the above-mentioned initiative were: to achieve a certain level of standardization (while maintaining the possibility of stylistic or practical synonymy); to uphold traditional terms (as opposed to theoretically backed terminological modernisation); 
to diffuse the use of practical, shorter, meaningful and suffixable terms. Following the general introduction, the initiative contained several synonymous lists, asking peers to choose the most relevant term from each. Further difficulties, not handled as terminological questions, were seen as unsolvable until a series of academic articles examined them in detail.

The final section of the document presented the idea of a Hungarian onomastic encyclopedia which would also have contained entries on the terminology of the field. The volume - which would have been edited by MIHÁLY HAJDÚ and ANDRÁs MEZÖ - would have followed the principles below: the collection of every term or periphrasis ever used in Hungarian onomastics; the creation of new terms if needed; the inclusion of synonymous terms (and terms to be avoided) with reference to preferred phrases; the analysis of certain terms as part of larger entries. The planned dictionary would have contained entries for three or four thousand terms and phrases. As a sample list of lexicological headwords in the original document illustrated, the goal of the planned volume was more similar to that of an encyclopaedia than of a dictionary. (Cf. also the sample list of headwords connected to by-names: HAJDÚ 2010: 25.)

The Onomastic Committee of the Academy discussed the proposal the following year and initially deemed it worthy of support. However, not much later the committee itself was disbanded following the reorganisation of the Academy, thus the project was stalled.

4.2. The question was revisited a few years later when the Névtani Értesitö, the periodical of Hungarian onomastic studies entered circulation in 1979. The editor of the journal, MIHÁLY HAJDÚ, published a slightly revised version of his pioneering debate article in the first issue (HAJDÚ 1979). The journal then published a number of responses and opinions - from onomasticians of different generations - the same year (Névtani Értesitö 1979. 2: 28-34, 1980. 3: 56-60). The professional reviewer of the first volumes of the journal also added his thoughts on several terms listed (KÁLMÁN 1982: 502-503). By then reviews of some of the glossaries of terms published in other languages were available in Hungarian linguistic journals (of the German, Finnish-Swedish, and Russian respectively: FEHÉRTÓI 1966, MIZSER 1979, UDVARI 1981).

Nevertheless, the promising revival of the subject did not last long, as at the time of other large linguistic projects the question remained slightly peripheral, while its supporters were distracted by other professional tasks. Furthermore, it seems that despite these efforts, such a concise and systematic review of Hungarian onomastic terminology was not backed strongly enough by the researchers of the field (HAJDÚ 2010: 26, cf. HOFFMANN 2003: 54).

4.3. The following attempt to summarise Hungarian onomastic terminology was made two decades later, in the first years of the new millennium. The practical bilingual (English-Hungarian) glossary compiled by JUDIT SZILVIA VÁRNAI was a preparatory auxiliary collection to aid a larger project connecting many fields of linguistics (VÁRNAI ed. n.d.). The simple 172-item glossary which was published online was based on the translation of the then current volume (2. History of the Study of Toponyms in the Uralian Languages. Debrecen, 2002) of the Onomastica Uralica series edited in Hungary, but published in English and Russian. (This practical connection to the volume may be the reason for the thematic bias towards toponomastics apparent in the glossary.) The 
introduction written to the online version of the bilingual glossary claims that unpublished sections of the term list also contain additional information (short definitions, notes, academic references, abbreviations, information on word class, cross-references). Furthermore, it indicated continuous work on the project. However, this initiative also stalled, and further work never saw publication, nor did any of its auxiliary work processes.

From a thematic and chronological point of view a published Italian-Hungarian glossary of onomastic terms must also be mentioned here (FÁBIÁN 2001). It contains the Italian definitions of Italian headwords as entries, with corresponding Hungarian terms and examples from both languages. The compilation was created for Hungarian students of Italian, and published as an appendix to a textbook containing a broad selection of Italian onomastic articles.

The above mentioned bilingual term lists were all organised - following the order of the foreign terms - to aid the translation and interpretation of foreign onomastic research in Hungarian. Inverse lists, however, with terms ordered according to their Hungarian alphabetical order were not published alongside these.

4.4. Later proposals also stressed the importance, and examined the possible guidelines of the creation of a dictionary of Hungarian onomastic terminology. Papers presented at onomastic conferences over the following years attempted to draw conclusions regarding questions and difficulties that had already been identified (JUHÁSZ 2004: 165-166, FARKAS 2008: 339-340). However, these individual initiatives were not followed by organised research and no actual steps were made. Research into the terminology of onomastics was renewed through the cooperation of a group of scholars (Andrea Bölcskei, Mariann Slíz and Tamás Farkas), inspired by the international work done in onomastic terminology, and the need for the harmonisation of the Hungarian and the international terminology of the field. They formed the Hungarian subgroup of the ICOS Terminology Group in 2011.

Their albeit informal, but consciously organised project has led to advances regarding the Hungarian terminology of onomastics. An overview of the history and current state of terminological research in Hungarian and international onomastics was published (FARKAS 2011). A workshop entitled Onomastics and Terminology was held in 2012 and invigorated new research into the field through a series of papers and a roundtable discussion. These papers (HOFFMANN 2012, FARKAS 2012, SLíz 2012, BÖLCSKEI 2012, BAUKO 2012) and a summary of the discussion (cf. BÖLCSKEI-FÓRIS 2012) were published in the same year in the Hungarian onomastic journal, Névtani Értesitö. Furthermore, over the past years certain general and thematic problems and questions of Hungarian onomastic terminology have been brought to the surface, at times directly as a result of the terminological work being carried out, or at others in connection to onomastic research on a broader scale. (Connected research and its topics are detailed below.)

It was in connection with the formation of this working group that work began on the Hungarian version of the Glossary of Terms for the Standarization of Geographical Names (cf. BÖLCSKEI 2013a), as did similar processes - also under the supervision of ANDREA BÖLCSKEI - to translate the Lists of Key Onomastic Terms. (For more detail on these projects see BÖLCSKEI 2017, in current volume). Plans were also drawn for a comprehensive terminological dictionary of Hungarian onomastics, its preparation and defining principles (FARKAS 2013). However, the research project in which these plans were 
outlined did not receive funding. Despite this setback research already underway has continued and the Hungarian versions of the two major international glossaries have been completed. The current bilingual volume, which contains the two glossaries of terms and attached studies, is also the result of this academic cooperation.

4.5. A comprehensive, in-depth and systematic dictionary of onomastic terminology is still missing from the list of Hungarian onomastic reference books. Let it suffice to quote two of the most prominent figures of Hungarian onomastics regarding this deficiency (translated from Hungarian). MIHÁLY HAJDÚ believed that "the standardization of onomastic terminology is one of the most important questions of our time" (HAJDÚ 2011: 345). While this remark may be slightly over-zealous it is certain that - as ISTVÁN HOFFMAN stated - "a volume which collected and defined the terms used in onomastics would aid the transparency and homogenisation of the field, even if aimed to be merely informative and not norm-defining" (HOFFMANN 2003: 55). These views are coherent with the principles expressed in the recent plans of such a dictionary mentioned above.

Thus, the creation of a Hungarian list, glossary or dictionary of onomastic terms which also takes international terminology into consideration - is a task still to be completed by Hungarian scholars of the field. Work in this direction would not only be useful in Hungarian and international onomastics but facilitate professional discourse and cooperation between many scientific and academic disciplines (cf. FARKAS 2013: 445).

5. Questions regarding the terminology of onomastics in Hungarian scholarly literature. The sections below summarise onomastic articles that address the general questions of terminological issues in onomastics, and offer an overview of papers regarding the terminology of the various subfields of Hungarian onomastic studies.

5.1. Comparatively few papers have been published on the general difficulties and problems - which are thus not focused on certain subfields - faced by the Hungarian terminology of onomastics. First of all, papers calling for the systematic and comprehensive processing of terminology may be listed here (see above for more detail). Others that be should mentioned here are those that examine terminology from a theoretic point of view, concentrating on its most problematic features and listing examples from onomastic studies. Articles of the latter type have mainly been written in the recent past and direct research towards certain thematic questions: what defines a term (SLÍz 2012); connections between theory and terminology (HOFFMANN 2012); reasons behind the formation of terms, factors influencing changes in terminology and the consequences of these changes (SLÍZ 2012); terminological deficiencies (FARKAS 2012, SLíz 2014); semantic questions and difficulties in general and the use of terminologies (FARKAS 2012, SLÍZ 2014); conflicts between terms of international (foreign) origin and traditional Hungarian terms (FARKAS 2012, SLÍz 2014); questions posed by the harmonisation and standardization of terminology (BÖLCSKEI 2012, 2017); comparisons of the onomastic terminology of the Hungarian and other languages (BAUKO 2012, SLíz 2014). These questions, and the results of research into them have also - in part - been published in foreign languages: the general state, characteristics and questions of Hungarian onomastic terminology (FARKAS 2014b); the results of the comparison of Slavic and Hungarian 
onomastic terminology (BAUKO 2015c); and the difficulties faced in the translation of the UNGEGN glossary of terms (BÖLCSKEI 2013b).

The terminology of onomastics was also given some attention in a monograph on the history of Hungarian place name studies (HOFFMANN 2003: 53-55), as well as in a review of the recent past and current state of Hungarian onomastics (SLÍZ 2015: 101-103). However, terminological aspects are most common in studies that concentrate on certain thematic units, or subfields of onomastics. Comprehensive studies, monographs, and papers on various topics of onomastics are at times even forced to answer, or clear terminological difficulties.

5.2. The following points will attempt to provide a summary of the most typical subjects and terminological problems in Hungarian onomastics. As the current study does not allow for an in-depth introduction of all concerned papers, research from the recent past has been prioritised, as these also provide information on earlier research into their respective fields.

5.2.1. In the formative period (or revival) of Hungarian onomastics, indicating the separation of the field, the Hungarian term for the discipline itself was given much attention (PAPP 1955: 258, BENKÖ 1960, MIKESY 1960). It was time that eventually settled this debate as a number of terms remain in use to the present day as synonyms: névtan 'name studies', névkutatás 'name research', névtudomány 'name science', and onomasztika 'onomastics'; while others did not become common in academic and scientific discourse (cf. HOFFMANN 2012: 127-128).

5.2.2. One of the most common and problematic points of Hungarian onomastic terminology was the use of helynév 'place name' or földrajzi név 'geographical name'. The question has been revisited multiple times with recurring arguments and criticism. Both terms are in use to the present day and choosing one over the other is a point of personal preference, or the traditions of certain scientific fields. (For more detail see HoFFMANN 2003: 53-55, 2012: 128-130.) It should be noted that the name of the disciple itself: helynévtan 'place name studies' or helynévkutatás 'place name research', and other elements of its specialised terminology - due to natural diversity and different theoretical approaches - did not draw much attention (for a detailed overview see HOFFMANN 2012: 130-132).

The creation of a new model for the analysis of place names (HOFFMANN 1993, 1999), however, brought terminological changes to light, as did later studies based on this categorization (cf. HOFFMANN 2012: 133-135). Furthermore, as the HOFFMANN place name typology model proved effective in (and adaptable to) the categorization of other types of proper names as well (cf. HoFFMANN 2007: 7-8), the terminology it introduced became known and used in other fields of Hungarian onomastics.

The terminology of the international standardization of geographical names and its translation to Hungarian (examined above) is a unique aspect of this field (for more detail on the question see BöLCSKEI 2017, in current volume). The goals of this terminology are to harmonise the terms used in different languages, to create missing terms and to define existing terms in detail. (On the terms used to denote the standardization of geographical names see BÖLCSKEI 2012: 176.) It is well known that interpreting one 
single term can lead to many theoretical and practical difficulties; an especially illustrative example of this, from the field of international geographical name standardization was the case of exonym (in Hungarian: exonima; cf. POKOLY 2013, POKOLY-BÖLCSKEIMIKESY 2015). Also, the use of standard név 'standard name' or standard névváltozat 'standard name form' itself presents terminological difficulties (cf. GYŐRFFY 2012).

5.2.3. Terms denoting certain types of anthroponyms proved to be the most problematic in Hungarian onomastic terminology. This is a result of the fact that terms originating from everyday experiences and spoken Hungarian are often insufficient or problematic in professional studies of the subject. This in turn is a result of their transparent general use as common nouns, the perspective they take, and changes in the lingualcultural context of the community. Furthermore, the family name + given name order used in the Hungarian language itself leads to several terminological difficulties when translating between Hungarian and other languages (cf. terms like first name, last name etc.). This topic illustrates the difficulties and inadequacies of terms of Hungarian origin from the viewpoint of onomastic theory and historical onomastics especially well (FARKAS 2014b: 17-18).

Attention was mainly drawn to the difficulties of term use in works attempting to provide a comprehensive and methodological overview of the Hungarian anthroponymic system. KATALIN J. SOLTÉSz in her substantial monograph on name theory (1979) attempted - largely unsuccessfully - to bring terminological changes into use on many points (for its review see HAJDÚ 1981: 109-110). While MIHÁLY HAJDÚ was always open to innovation, in this case he preferred a different approach: his attempt to clarify the terminological difficulties of the field in his reference work on personal names was centred around reviewing the possibilities, and choosing one of the terms already in use (HAJDÚ 2003: 151-153, 347, 638, 732; cf. its review which emphasised his methodological approach to terminology: B. GERGELY 2007: 253-255). It would be useful to review the terminology of the field to ease interdisciplinary work (cf. for example a contrastive study on the terminology of onomastics and name law: SLíz, in press). Furthermore, a new typology of anthroponyms devised by ISTVÁN HOFFMANN (2008, also cf. HOFFMANNТо́тH 2015) automatically lead to the formation of new terms in Hungarian anthroponomastics (even though the original goal was only to offer possible terms for certain elements, cf. HOFFMANN 2008: 10, $1^{\text {st }}$ footnote). Further research into the typology of anthroponyms may yet bring further changes in the terminology used in their study (cf. SZENTGYÖRGYI 2016).

Clarifying Hungarian anthroponomastic terminology is a current question for scholars of much researched historical personal name types (in detail see SLíz 2010), and also of barely researched other, "substitute" names (helyettesito" nevek, to use the disputable term of J. SOLTÉSZ 1979: 59; cf. also HAJDÚ 2006). A newly formed name type, online nicknames also brought new terms into scholarly discourse (cf. RAÁTZ 1999: 263, 2011: 184-185).

Naturally, questions regarding the terminology of anthroponomastics reach beyond simply denoting certain name types. Personal name, and especially family name changes, for example, were examined in great detail in connection with a targeted research project. A result of this was an analysis of the (surprisingly large) historical and present day terminology, the differences in the common usage and technical usage of words in the field (FARKAS 2008), as well as the proposal of an innovative typology for personal 
name changes and the connected terminology (HAJDÚ 2009, VÖRÖS 2009). However, the concrete topic, when placed into the broader framework of a general theoretical model (FARKAS 2015b, cf. FARKAS 2016), could only become describable through different terms known from earlier works (cf. HOFFMANN 1993, 1999; also TÓTH, V. 2008; N. FODOR 2010: 115-120).

5.2.4. Other name types besides toponyms and anthroponyms have cultivated much less interest in Hungarian onomastics. The lack of theoretical work on certain topics is often illustrated by terminological deficiencies, too, such as the lack of an equivalent term for the internationally accepted chrematonym. Terminological innovation in such fields depends on in-depth research into smaller aspects (e.g. on the names of human made structures, buildings, and institutions; see HÁRI 2010).

On the other hand, terminological detail has become more and more common in literary onomastics in past years. The ground-breaking monograph entitled Az irodalmi névadás [Literary name giving] by MIKLÓs KOVALOVSZKY (1934) had a lasting effect on the terminology of the field. Thus, clarifying the differences of irói névadás 'authorial name giving' and irodalmi névadás 'literary name giving' was seen as a relevant task not only half a century ago, but also in the recent past (MIKESY 1959; KOROMPAY 2011; T. SOMOGYI 2015: 208; TÓTH, L. 2015: 203-206; VÁCZINÉ TAKÁCS 2016: 9-18). The comprehensive term - introduced in part to replace the terms mentioned above irodalmi névtan 'literary name studies' is itself a rather new term in Hungarian academic writing (cf. TÓTH, L. 2015: 206; VÁCZINÉ TAKÁCS 2016: 17). Recent articles have called for a review of the terms currently used - originating from KOVALOVSZKY (1934) and earlier, classical works - to denote the different types of proper names used in literary works (cf. TÓTH, L. 2015; VÁCZINÉ TAKÁCS 2016). Recently completed, and in-work doctoral dissertations have achieved, and indicate, quick progress in this regard.

5.2.5. Onomastic studies connected to other dimensions of language use (temporality, space, social and cultural aspects) represent further subfields in the discipline of onomastics. The most traditional of these is historical onomastics, the name of which has always been beyond question: történeti névtan 'historical name studies', or névtörténet 'name history'. The name of the newest subfield, socioonomastics has also been widely accepted as szocioonomasztika 'socio-onomastics', or névszociológia 'name sociology'. These terms are the onomastic equivalents of the generally used Hungarian terms for the respective fields of linguistic studies, i.e. historical linguistics and sociolinguistics (cf. FARKAS 2014a, with emphasis 14-17). The term to denote research into geographical distribution of onomastic phenomena, however, has been much debated in the past decades, mainly by scholars also involved in dialectological studies (e.g. ÖRDÖG 1989: 29, 1991, 2010; HAJDÚ 2002; JUHÁSZ 2004: 166-169, 2010: 31; for a more recent summary, see FARKAS 2014a: 15, and for a critical review, see N. FODOR 2014: 24-27). At the present the most common term for the discipline seems to be névföldrajz 'name geography', the onomastic equivalent of nyelvföldrajz 'language geography'.

6. Native language onomastic terminology in the context of international onomastics. This final section will focus on the interrelation and connections between Hungarian and international onomastic terminology and work within the field, and how 
native language work and research can be treated in an increasingly international academic and scientific field (cf. FARKAS 2015a: 33-41).

6.1. The terminology of onomastics in Hungarian is characterised by a high number of native terms, next to which terms of an international origin are less typical (FARKAS 2014b: 15-17, SLÍz 2014: 149-252). International terms are rarely borrowed directly and also rarely entice terminological innovation in Hungarian. (For the latter cf. the terms used by JÁN BAUKO, based on terms common in international onomastics, but unusual in Hungarian name studies: gasztroantroponima, orohodonima; cf. BAUKO 2015a: 76, 127). However, it should also be noted that certain traditional Hungarian terms often indicate a foreign - usually German - influence, or may have been formed through direct translation. The terms névkutatás 'name research' (cf. Namenforschung) and helynév 'place name' (cf. Ortsname) are also examples of such.

Besides the above, in some cases unique terms of Hungarian onomastics must also be translated to other languages. The terms used in foreign language articles introducing the theoretical models devised by ISTVÁN HOFFMANN are examples of these challenges (see e.g. HOFFMANN 1993: 153-162; TÓTH, V. 2005; HOFFMANN-TÓTH 2015).

6.2. Studies published on the terminologies of other languages, and activities in the standardization of international onomastic terminology may prove fruitful for Hungarian onomastics. Papers examining certain Hungarian terminological questions have at times been written with an outlook on the results and difficulties of the onomastic terminology of other languages. This has proven profitable not only in largely unresearched fields, but also regarding traditional and newer terms as well (e.g. cf. MIKESY 1960; HAJDÚ 2003: 151-153; VINCZE 2004: 187-188; FARKAS 2008: 336; RAÁTZ 2008: 444; BÖLCSKEI 2010: 84-85; HÁRI 2010: 102-103; TÓTH, L. 2015). There are also a few examples of studies comparing aspects of international and Hungarian onomastic terminology (a methodological comparison of the Hungarian and Slovakian/Slavic terminologies: BAUKO 2015c; on a narrower topic, Finnish and Hungarian: TAKÁCS, in press).

Publishing the results of Hungarian terminological research in the international scene is an important task. A number of studies written in foreign languages detailing certain questions and characteristics of Hungarian onomastic terminology - as detailed above have been published in the recent past (BÖLCSKEI 2013b, FARKAS 2014b, BAUKO 2015c). The current volume, containing the Hungarian version of the ICOS and UNGEGN glossaries, is itself a bilingual publication in English and Hungarian.

6.3. In past years Hungarian researchers have also begun to work within the ICOS Terminology Group. While there is also a Slovakian Hungarian scholar involved in the project aimed at building a digital terminology database organised by the Slovak Onomastic Commission, in which current plans hope to include Hungarian terms as well (BAUKO 2015b: 73).

A few bilingual term lists of Hungarian onomastics have been published before the current versions of the ICOS and UNGEGN glossaries (English-Hungarian: VÁRNAI ed. n.d., Italian-Hungarian: FÁBIÁN 2001). It should also be noted that the earlier version of the UNGEGN glossary of terms also had a Hungarian translation (FÖLDI 1992), as did glossaries on the terminology of undersea feature names (FÖLDI 1979, MÁRTON-DUTKÓ 
eds. 2003: 17-30, reprinted in MÁRTON 2012: 278-279, 305-318; on their historical background see MÁRTON 2012: 184-192).

6.4. Published works such as those enumerated above facilitate cooperation between Hungarian, and international onomastics (and other concerned disciplines), which would be impossible without clear-cut terminological connections. Common interest in international onomastics and its terminology is not only important, due to the theoretical advances made within it. It is the basic connection of a primarily native language - albeit one with an international scope and many international connections - onomastic community with its international counterpart.

\section{Internet Resources}

ICOS website $=\underline{\text { https: } / / \text { www.icosweb.net/drupal } /}$

ICOS terminology $=\underline{\text { https: } / / \text { icosweb.net/drupal/terminology }}$

UNGEGN website $=$ https://unstats.un.org/unsd/geoinfo/UNGEGN/

UNGEGN terminology = https://unstats.un.org/unsd/geoinfo/UNGEGN/publications.html

\section{Bibliography}

B. Gergely, Piroska 2007. Hajdú Mihály: Általános és magyar névtan [Mihály Hajdú: General and Hungarian Onomastics. (Review)]. Magyar Nyelvör 131: 253-258.

BAUKO, JÁNOS [JÁN] 2009. Ragadványnév-vizsgálatok kétnyelvü környezetben. (Négy szlovákiai magyar település ragadványnévrendszere) [Investigation of Nicknames in a Bilingual Environment. (The System of Nicknames in Four Hungarian Settlements in Slovakia)]. Nitra; Budapest: Univerzita Konštantína Filozofa v Nitre Fakulta stredoeurópskych štúdií; Magyar Nyelvtudományi Társaság.

BAUKO, JÁNOS [JÁN] 2012. A magyar és a szlovák (szláv) névtani terminológia összevetése [Comparing Hungarian and Slovakian (Slavic) Onomastic Terminology]. Névtani Értesitö 34: 157-166.

BAUKO, JÁNOS [JÁN] 2015a. Bevezetés a szocioonomasztikába [Introduction to Socio-onomastics]. Nitra: Univerzita Konštantína Filozofa v Nitre Fakulta stredoeurópskych štúdií.

BAUKO, JÁNOS [JÁN] 2015b. Magyar névkutatás a határokon túl [Hungarian Onomastics in Countries Neighbouring Hungary]. In: FARKAS, TAMÁs - SLíz, MARIANN eds., Magyar névkutatás a 21. század elején. Budapest: Magyar Nyelvtudományi Társaság; ELTE Magyar Nyelvtudományi és Finnugor Intézet. 63-89.

BAUKO, JÁN [JÁNOS] 2015c. Komparácia slovenských a mad’arských onomastických termínov. In: BALleKovÁ, KATARÍNA - KrÁliK, L'UBOR - MúCsKOvÁ, GABRIEla eds., Jazykovedné štúdie XXXII. Prirodzený vývin jazyka a jazykové kontakty. Bratislava: Veda. 254-262.

BENKÖ, LORÁND 1960. Megjegyzések terminus technikusokról [Notes on Terms]. Magyar Nyelv 56: $238-240$.

BEZLAJ, FRANCE et al. 1983. Osnoven sistem i terminologija na slovenskata onomastika. Osnovnaja sistema i terminologija slavjanskoj onomastiki. Grundsystem und Terminologie der slawischen Onomastik. Skopje: Makedonska akademija na naukite i umetnostite; Megunaroden komitet na slavistite; Komisija za slovenska onomastika. 
BÖLCSKEI, ANDREA 2010. A magyar településnevek korrelációs rendszerének alakulása a természetes névadás korszakában [The Correlational System of Hungarian Settlement Names in the Period of Non-official Place-naming Practices]. A Károli Gáspár Református Egyetem Magyar Nyelvtudományi Tanszékének Kiadványai 2. Budapest: Károli Gáspár Református Egyetem Magyar Nyelvtudományi Tanszéke.

BölCSKEI, ANDREA 2012. A helynév-standardizáció terminológiájáról [On the Terminology of Geographical Names Standardization]. Névtani Értesitö 34: 167-178.

BölCSKeI, ANDREa 2013a. Az „UNGEGN Glossary of Terms for the Standardization of Geographical Names" címü terminusjegyzék magyar változatának elkészítéséről [On Preparing the Hungarian Version of the UNGEGN Document Entitled "Glossary of Terms for the Standardization of Geographical Names"]. Névtani Értesitö 35: 11-21.

BÖLCSKEI, ANDREA 2013b. Challenges in updating the Hungarian terminology for geographical names standardization. Magyar Terminológia 6/2: 153-168. https://doi.org/10.1556/1206.2013.6.2.3

BölcskeI, ANDrea 2017. The Hungarian Versions of Two International Onomastic Terminological Glossaries. In: BölCSKeI, ANDREA - FARKAS, TAMÁs - Slíz, MARIANN eds., Magyar és nemzetközi névtani terminológia / Hungarian and International Onomastic Terminology. Uppsala; Budapest: International Council of Onomastic Sciences; Magyar Nyelvtudományi Társaság. 85-98. https://doi.org/10.26546/5061110.10

BöLCSKeI, ANDREA - FóRIS, ÁGOTA 2012. Névtan és terminológia 2: Névtan és egységesítés [Onomastics and Terminology 2: Onomastics and Standardization]. Névtani Értesitö 34: $125-126$.

Brendler, Andrea - Brendler, Silvio Hrsg. 2004. Namenarten und ihre Erforschung. Ein Lehrbuch für das Studium der Onomastik. Lehr- und Handbücher zur Onomastik 1. Hamburg: Baar-Verlag.

BuchKo, Dmytro Hryhorovych - TKachova, Natalia Vasylivna 2012. Slovnyk ukrains'koi onomastychnoi terminolohii. Kharkiv: Ranok. [= БУЧКО, ДМИТРО ГРИГОРОВИч - ТКАЧОВА, НАТАЛІЯ ВАСИЛІВНА 2012. Словник української ономастичної термінологї. Харків: Ранок.]

Dorion, Henri - Poirier, JeAn 1975. Lexique des termes utiles à l'étude des noms de lieux. Quebec: French and European Publications Inc.

FÁBIÁN, ZsUZSANNA 2001. Glossario dei termini piú importanti dell'Onomastica. In: FÁBIÁN, Zsuzsanna ed., Antologia di Onomastica Italiana. Budapest: Eötvös Loránd Tudományegyetem Bölcsészettudományi Kar Olasz Nyelv és Irodalom Tanszék. 291-299.

FARKAS, TAMÁS 2008. Szemlélet és terminológia a névkutatásban: a hivatalos magyar családnévváltoztatások kérdései [Approach and Terminology in Onomastic Research: The Questions of Official Family Name Changes in Hungary]. In: BöLCSKEI, ANDREA - N. CsÁsZI, ILDIKÓ eds., Név és valóság. A VI. Magyar Névtudományi Konferencia elöadásai. Balatonszárszó, 2007. június 22-24. A Károli Gáspár Református Egyetem Magyar Nyelvtudományi Tanszékének Kiadványai 1. Budapest: Károli Gáspár Református Egyetem Magyar Nyelvtudományi Tanszéke. 332-341.

FARKAS, TAMÁS 2011. Terminológiai munkálatok a névkutatás területén [Terminological Works in Onomastics]. Névtani Értesítö 33: 203-212.

FARKAS, TAMÁS 2012. Szempontok a magyar névtani terminológia megítéléséhez [On Some Characteristics and Problems of Hungarian Onomastic Terminology]. Névtani Értesitó 34: 139-148. 
FARKAS, TAMÁs 2013. Egy magyar névtani terminológiai szótár tervéröl [On a Plan of a Dictionary of Hungarian Onomastic Terms]. In: TóTH, SzERGEJ ed., Társadalmi változások - nyelvi változások. Alkalmazott nyelvészeti kutatások a Kárpát-medencében. A XXII. MANYE Kongresszus elöadásai. Szeged, 2012. április 12-14. A MANYE Kongresszusok Előadásai 9. Budapest; Szeged: MANYE; Szegedi Egyetemi Kiadó Juhász Gyula Felsőoktatási Kiadó. 442-445.

FARKAS, TAMÁS 2014a. Dimenzionális szemlélet a névkutatásban. Általános kérdések és a családnévkutatás példája [The Dimensional Approach in Onomastics. General Questions and the Example of Family Name Research]. Névtani Értesitö 36: 9-22.

FARKAS, TAMÁS 2014b. Onomastic Terminology in Hungarian - Situation, Problems and Needs. In: Tort i Donada, JoAn - Montagut i Montagut, Montserrat eds., Els noms en la vida quotidiana. Actes del XXIV Congrés Internacional d'ICOS sobre Ciències Onomàstiques. I Names in daily life. Proceedings of the XXIV ICOS International Congress of Onomastic Sciences. Biblioteca Tècnica De Política Lingüística 11. Barcelona: Generalitat de Catalunya. 14-20. http://www.gencat.cat/llengua/BTPL/ICOS2011/003.pdf \& https://doi.org/10.2436/15.8040.01.3

FARKAS, TAMÁS 2015a. A nemzetközi névkutatás és magyar kapcsolatai [International Onomastics and Its Hungarian Relations]. In: FARKAS, TAMÁs - SLÍz, MARIANN eds., Magyar névkutatás a 21. század elején. Budapest: Magyar Nyelvtudományi Társaság; ELTE Magyar Nyelvtudományi és Finnugor Intézet. 23-47.

FARKAS, TAMÁS 2015b. A magyar családnevek változástipológiájáról [The Typology of Changes in the History of Hungarian Family Names]. Magyar Nyelv 111: 395-408. https://doi.org/10.18349/ MagyarNyelv.2015.4.395

FARKAS, TAMÁS 2016. The Typology of Changes in the History of Hungarian Surnames. In: Hough, CAROlE - IzDEBSKa, Daria eds., 'Names and Their Environment'. Proceedings of the 25th International Congress of Onomastic Sciences, Glasgow, 15-19 August 2014. 3. Anthroponomastics. Glasgow: University of Glasgow. 55-64. http://www.icos2014.com/wp-content/ uploads/icos2014_v3_55.pdf

FeHÉRTÓi, KATALIN 1966. A német névtudomány két újdonsága [Two Novelties in German Onomastics]. Magyar Nyelv 62: 245-247.

FÖLDI, ERVIN 1979. Elöterjesztés a tenger alatti domborzati nevekröl [Report on Names for Seabed Relief Features]. A Földrajzinév-Bizottság 32. ülésének jegyzőkönyve. Manuscript. Budapest.

FöLDI, ERVIN 1992. ENSZ földrajzinév-egységesítési szakkifejezések szótára [UN Technical Terminology Employed in the Standardization of Geographical Names]. Névtani Értesitö 14: 127-138.

Galkowski, Artur 2010. Problemi di terminologia onomastica. Contributi per un dibattito. Rivista Italiana di Onomastica 16: 604-624.

GALKOWSKI, ARTUR 2012. Aktualizowana lista podstawowych haset terminologii onomastycznej w języku polskim. http://onomastyka.uni.lodz.pl/strona-glowna/terminologia-polska

GYŐRFFY, ERZSEBET 2007. A svéd névtudományról és helynévkutatásról [Onomastics and Place Name Studies in Sweden]. Névtani Értesitö 29: 247-257.

GYÖRFFY, ERZSÉBET 2012. A hivatalos név terminus [The Term Official Name]. Magyar Nyelvjárások 50: 27-35.

HAJdú, MinÁly 1974a. Vitainditó a névtudomány müszavairól [Introduction to a Debate on Onomastic Terms]. Bokor Levelek 12. Manuscript. Budapest.

HAJDÚ, MiHÁLY 1974b. Elöterjesztés a magyar névtudomány müszavainak egységesitéséröl [A Proposal on the Standardization of Hungarian Onomastic Terms]. Manuscript. Budapest.

HAJDÚ, MiHÁLy 1979. A magyar névtudomány müszavai [Terms in Hungarian Onomastics]. Névtani Értesitő 2: 18-28. 
HAJDÚ, MihÁly 1981. J. Soltész Katalin, A tulajdonnév funkciója és jelentése [Katalin J. Soltész: The Function and Meaning of Proper Names. (Review)]. Magyar Nyelv 77: 109-113.

HaJdÚ, MiHÁly 2002. Tulajdonnév és dialektológia [Proper Names and Dialectology]. In: SzABÓ, GÉZA - Molnár, Zoltán - GutTMann, MikLós eds., IV. Dialektológiai Szimpozion. Szombathely, 2001. augusztus 23-25. A Berzsenyi Dániel Tanárképző Főiskola Magyar Nyelvészeti Tanszékének Kiadványai 5. Szombathely: Berzsenyi Dániel Főiskola Magyar Nyelvészeti Tanszéke. 104-119.

Hajdú, MinÁly 2003. Általános és magyar névtan. Személynevek [General and Hungarian Onomastics. Personal Names]. Budapest: Osiris Kiadó.

HAJDÚ, MiHÁly 2006. Álnév - fedőnév - jelige - internetnév [Pseudonym - Code Name - Code Word - Internet Name]. In: Mártonfi, AtTILA - PAPP, KornÉlia - Slíz, MARIANN eds., 101 irás Pusztai Ferenc tiszteletére. Budapest: Argumentum. 257-266.

HAJDÚ, MiHÁly 2009. A névváltozások és névváltoztatások rendszere [The System of Changes of Personal Names]. In: FARKAS, TAMÁs - KozMA, IsTVÁn eds., A családnév-változtatások történetei időben, térben, társadalomban. Budapest: Gondolat Kiadó; Magyar Nyelvtudományi Társaság. 29-40.

Hajdú, Minály 2010. Közös tervek Mezö Andrással [Common Plans with András Mező]. In: P. LAKATOS, IlONA - SeBeStYÉN, Zsolt eds., Emlékkönyv Mezö András tiszteletére. Nyíregyháza: Bessenyei Könyvkiadó. 23-28.

HAJDÚ, MiHÁLy 2011. Farkas Tamás, Családnév-változtatás Magyarországon [Tamás Farkas: Family Name Changes in Hungary. (Review)]. Magyar Nyelv 107: 345-347.

HÁRI, GYUla 2010. Épületnév, építménynév, létesítménynév [Names for Houses, Buildings and Establishments]. Névtani Értesitö 32: 99-116.

HARVALÍK, MiLAN 2005. Towards a new millennium - towards a common onomastic terminology? In: Brylla, Eva - WahlBerg, Mats eds., Proceedings of the 21st International Congress of Onomastic Sciences. Uppsala 19-24 August 2002. Uppsala: Språk- och folkminnesinstitutet. 1: $160-171$

HARVALÍK, MiLAN 2007. K voprosu o sovremennoj onomastičeskoj terminologii. Voprosi onomastiki 2/4: 5-13. [= ГАРВАЛИК, МилАН 2007. К вопросу о современной ономастической терминологии. Вопросы ономастики 2/4: 5-13.]

Harvalík, Milan 2014. Towards a common onomastic terminology? The next step. In: TORT I Donada, JoAn - Montagut i Montagut, Montserrat eds., Els noms en la vida quotidiana. Actes del XXIV Congrés Internacional d'ICOS sobre Ciències Onomàstiques. / Names in daily life. Proceedings of the XXIV ICOS International Congress of Onomastic Sciences. Biblioteca Tècnica De Política Lingüística 11. Barcelona: Generalitat de Catalunya. 21-25. http://www.gencat.cat/llengua/BTPL/ICOS2011/004.pdf \& https://doi.org/10.2436/15.8040.01.4

HaRVALíK, Milan - CAFFARELli, ENZo 2007. Onomastic terminology: an international survey / Terminologia onomastica: un'inchiesta internazionale. Rivista Italiana di Onomastica 13: 181-220.

HENNO, KAIRIT - PÄLl, PEETER 2003. Onomastika termineid. http://www.eki.ee/nimeselts/nimeterm.htm Hoffmann, István 1993. Helynevek nyelvi elemzése [Linguistic Analysis of Place Names]. A Debreceni Kossuth Lajos Tudományegyetem Magyar Nyelvtudományi Intézetének Kiadványai 61. Debrecen: Debreceni Kossuth Lajos Tudományegyetem Magyar Nyelvtudományi Intézete.

HofFMANN, IsTVÁN 1999. A helynevek rendszerének nyelvi leírásához [On the Linguistic Description of Place Name Systems]. Magyar Nyelvjárások 37: 207-216. 
HoffmanN, István 2002. Magyar névkutatás az ezredfordulón [Hungarian Onomastics at the Turn of the Millennium]. In: Hoffmann, István - JuHÁsz, Dezsö - PÉntek, JÁnos eds., Hungarológiai és dimenzionális nyelvszemlélet. Elöadások az V. Nemzetközi Hungarológiai Kongresszuson. Debrecen; Jyväskylä: n.p. 9-22.

HofFMANN, IstVÁN 2003. Magyar helynévkutatás 1958-2002 [Hungarian Place Name Research 1958-2002]. A Magyar Névarchívum Kiadványai 7. Debrecen: Debreceni Egyetem Magyar Nyelvtudományi Tanszék.

Hoffmann, István 2007. Helynevek nyelvi elemzése [Linguistic Analysis of Place Names]. 2nd edition. Segédkönyvek a nyelvészet tanulmányozásához 67. Budapest: Tinta Könyvkiadó.

Hoffmann, István 2008. A személynévrendszerek leírásához [On the Description of Personal Name Systems]. Magyar Nyelvjárások 46: 5-20.

HofFMANN, ISTVÁN 2012. Elmélet és terminológia a magyar helynévkutatásban [Theory and Terminology in Hungarian Toponomastics]. Névtani Értesitö 34: 127-137.

HOFFMANN, ISTVÁN - TÓTH, VALÉRIA 2015. Viewpoints on the cognitive-pragmatic description of personal names. Word: Journal of the International Linguistic Association 61: 141-164. https://doi.org/10.1080/00437956.2015.1033832

J. SoltÉsz, KATAlin 1979. A tulajdonnév funkciója és jelentése [The Function and Meaning of Proper Names]. Budapest: Akadémiai Kiadó.

JuHÁsz, DEzső 2004. A névtan néhány terminológiai és tudományrendszertani kérdéséröl [On Some Terminological and Taxonomic Questions of Onomastics]. In: FARKAS, FerENC ed., Magyar névtani kutatások itthon és határainkon túl. Névtani tanácskozás Jászberényben. 2003. október 17-18. Budapest: Magyar Nyelvtudományi Társaság; Szent István Egyetem Jászberényi Főiskolai Kar; TIT Jászsági Szervezete; Jászok Egyesülete. 165-169.

JuHÁsz, Dezsö 2010. A személynevek mint a nyelvföldrajz tárgyai [Personal Names as Subjects of Linguistic Geography]. In: Vörös, FERENC ed., A nyelvföldrajztól a névföldrajzig. A 2010. június 8-i szombathelyi tanácskozás elöadásai. A Magyar Nyelvtudományi Társaság Kiadványai 234. Budapest; Szombathely: Magyar Nyelvtudományi Társaság; NyME Savaria Egyetemi Központ. 31-39.

Kaleta, Zofia 1998. Kierunki i metodologia badań. Terminologia. In: Rzetelska-Feleszko, EwA ed., Polskie nazwy wlasne. Encyklopedia. Warszawa; Kraków: Wydawnictwo Instytutu Języka Polskiego PAN. 45-81.

KÁlmÁN, BÉla 1982. Névtani Értesítő. Szerk. Hajdú Mihály és Mező András. 2-5. szám [Mihály Hajdú and András Mező eds.: Névtani Értesítő No. 2-5. (Review)]. Magyar Nyelv 78: 502-505.

Kiviniemi, EERO - PitKÄNEN, Ritva-LiISA - Zilliacus, KuRT eds. 1974. Nimistöntutkimuksen terminologia. Terminologin inom namnforskningen. Castrenianumin toimitteita 8. Helsinki: Castrenianum.

KOROMPAY, KLÁRA 2011. Az irodalmi névadás fogalmáról [On the Concept of Name Giving in Literature]. Létünk 41/3: 86-93.

Kovalovszky, Miklós 1934. Az irodalmi névadás [Name Giving in Literature]. A Magyar Nyelvtudományi Társaság Kiadványai 34. Budapest: Magyar Nyelvtudományi Társaság.

MARCATO, CARLa 2009. Nomi di persona, nomi di luogo. Introduzione all'onomastica italiana. Bologna: Il Mulino.

MÁRTON, MÁTyÁs 1992. A magyar tengerfenék-domborzati nevek megalkotásáról [Creating the Undersea Feature Names in the Hungarian Language]. Névtani Értesitö 14: 84-116. 
MÁRTON, MÁTYÁs 2012. A világtenger kartográfus szemmel [World Oceans with a Cartographer's Eyes]. Budapest: Eötvös Loránd Tudományegyetem Informatikai Kar Térképtudományi és Geoinformatikai Tanszék.

MÁRTON, MÁTYÁs - DutKó, ANDRÁs ÁKos eds. 2003. Standardization of Undersea Feature Names / Tengerfenék-domborzati képzödmények neveinek egységesitése. 2. angol-magyar változat. 2nd English-Hungarian Version. Manuscript. Budapest.

MiKeSY, SÁNDOR 1959. Írói névadás - irodalmi névadás [Names in Literature - Literary Onomastics]. Magyar Nyelv 55: 110-112.

MiKeSY, SÁNDOR 1960. Mi legyen az onomasztika magyar neve [What Should be the Hungarian Term for Onomastics]? Magyar Nyelv 56: 236-238.

MizSER, LAJOS 1979. Három finn névtudományi munka [Three Works on Finnish Onomastics]. Magyar Nyelv 75: 246-250.

N. FODOR, JÁNOS 2010. Személynevek rendszere a kései ómagyar korban. A Felsö-Tisza-vidék személyneveinek nyelvi elemzése (1401-1526) [The System of Personal Names in the Late Old Hungarian Language. Linguistic Analysis of Personal Names of Northeast Hungary (1401-1526)]. Magyar Névtani Értekezések 2. Budapest: ELTE BTK Magyar Nyelvtörténeti, Szociolingvisztikai, Dialektológiai Tanszéke.

N. FODOR, JÁNOS 2014. A történeti személynévföldrajz mint a nyelvföldrajz egyik kutatási területe I. A nyelvföldrajzi módszer a névtani kutatásokban [The Geography of Historical Personal Names as a Research Area of Geolinguistics. Part I. Name Geographic Methods in Name Studies]. Névtani Értesítö 36: 23-41.

NimCHUK, VASYL' VASYL'OVYCH 1966. Ukrains'ka onomastychna terminolohia. Povidomlennia Ukrains'koi onomastychnoi komisii 1: 24-43. [= НІмчук, ВАСиль ВАСильОВич 1966. Українська ономастична термінологія. Повідомлення Украӥнської ономастичної комісії 1: 24-43.]

NySTRÖM, STAFFAN 2014. The terminological work of UNGEGN and ICOS - a presentation and a comparison. In: TORT i DONADA, JOAN - Montagut i MOnTAgut, MONTSERrat eds., Els noms en la vida quotidiana. Actes del XXIV Congrés Internacional d'ICOS sobre Ciències Onomàstiques. / Names in daily life. Proceedings of the XXIV ICOS International Congress of Onomastic Sciences. Biblioteca Tècnica De Política Lingüística 11. Barcelona: Generalitat de Catalunya. 52-57. http://www.gencat.cat/llengua/BTPL/ICOS2011/008.pdf \& https://doi.org/10.2436/15. $\underline{8040.01 .8}$

ÖRDÖG, FERENC 1989. Helynévgyüjteményeink mint az onomatodialektológia forrásai [Hungarian Place Name Repertories as Sources of Onomato-dialectology]. Baranyai Müvelödés 1989/3: $27-33$.

ÖRDÖG, FERENC 1991. Személyneveink onomato-dialektológiai vizsgálatáról [On the Onomatodialectal Analysis of the Hungarian Personal Names]. In: HAJdú, MiHÁLy ed., Emlékkönyv Benkö Loránd hetvenedik születésnapjára. Budapest: ELTE. 488-496.

ÖRDÖG, FERENC 2010. Névföldrajz, onomatodialektológia, névdialektológia [Name Geography, Onomato-dialectology, Name Dialectology]. In: VÖRÖS, FERENC ed., A nyelvföldrajztól a névföldrajzig. A 2010. június 8-i szombathelyi tanácskozás elöadásai. A Magyar Nyelvtudományi Társaság Kiadványai 234. Budapest; Szombathely: Magyar Nyelvtudományi Társaság. 127-133.

PAPP, LÁSZLÓ 1955. Szabó István: Bács, Bodrog és Csongrád megye dézsmalajstromai 1522-böl [István Szabó: 1522 talliage lists of Bács, Bodrog and Csongrád counties (Review)]. Magyar Nyelv 51: 258-263.

PETR, JAN 1969. Lužickosrbská onomastická terminologie. Zpravodaj Mistopisné komise ČSAV 10: $538-552$. 
PODOL'SKAJA, NATAL'JA VladimirovNA 1978. Slovar' russkoj onomastičeskoj terminologii. Moskva: Nauka. [= ПОДОЛЬСКАЯ, НАТАЛЬЯ ВЛАДИМИРОВНА 1978. Словарь русской ономастической терминологии. Москва: Наука.]

PodOL'SKAJA, NATAL'JA VladimiRovna 1988. Slovar' russkoj onomastičeskoj terminologii. Moskva: Nauka. 2nd edition. [= ПодОЛьСКАЯ, НАТАЛЬя ВЛАДИМИРОВНА 1988. Словарь русской ономастической терминологии. Москва: Наука.]

POKOLY, BÉla 2013. Az exonima kifejezés értelmezésének változása a földrajzinév-egységesítés nemzetközi gyakorlatában [Changing Definitions of the Term Exonym in the International Practice of Geographical Names Standardization]. Névtani Értesitó 35: 71-75.

PoKOly, BÉlA - BÖlCSKEI, ANDREA - MiKESY, GÁBOR 2015. The exonym/endonym divide: Examples highlighting different aspects for defining the terms. In: JoRdan, PETER - WoOdMan, PAul eds., Confirmation of the Definitions. Proceedings of the 16th UNGEGN Working Group on Exonyms Meeting, Hermagor, 5-7 June 2014. Hamburg: Verlag Dr. Kovac. 155-168.

RAÁTZ, JudiT 1999. Intern Otto, Angicica, Lütyö és a többiek, azaz névválasztás a számítógépes csevegöcsatornán [Intern Otto, Angicica, Lütyö and Others, i.e. Name Choice in Internet Chat Forums]. Névtani Értesítö 21: 262-266.

RAÁtZ, Judit 2008. Névadás az interneten [Naming Practices on the Internet]. In: BölcskeI, ANDREA - N. Császi, ILDikó eds., Név és valóság. A VI. Magyar Névtudományi Konferencia elöadásai. Balatonszárszó, 2007. június 22-24. A Károli Gáspár Református Egyetem Magyar Nyelvtudományi Tanszékének Kiadványai 1. Budapest: Károli Gáspár Református Egyetem Magyar Nyelvtudományi Tanszéke. 443-450.

RAÁTZ, JUDIT 2011. Nick as self-attributed name. Nouvelle Revue d'Onomastique 53: 183-209.

ROOM, AdRIAn 1996. An Alphabetical Guide to the Language of Name Studies. Lanham (MD); London: The Scarecrow Press.

Rzetelska-Feleszko, Ewa - Cieślikowa, Aleksandra - Duma, Jerzy eds. 2002-2003. Słowiańska onomastyka. Encyklopedia 1-2. Warszawa; Kraków: Towarzystwo Naukowe Warszawskie.

SCHMIDT, Tом 1981. Fagordliste for norsk namnegransking. Oslo: Institutt for namnegransking Universitetet i Oslo.

SLíz, MARIANN 2010. A történeti személynévkutatás terminológiájához [On Terminology of Historical Personal Name Research]. Névtani Értesitö 32: 157-172.

SLíz, MaRianN 2012. Terminusok keletkezése és változása [Appearance and Change of Terms]. Névtani Értesitö 34: 149-156.

SLíz, MARIANN 2014. A terminológiai egységesülés hiányának következményei a névtudományban [The Consequences of the Lack of Unified Terminology in Onomastics]. In: LENGYEL, KLÁRA - VesZELsZKi, ÁGNES eds., Tudomány, technolektus, terminológia. A tudományok, szakmák nyelve. Budapest: Éghajlat Könyvkiadó. 249-258.

SLíz, Mariann 2015. Általános névtani kérdések [General Onomastics]. In: FARKAS, TAMÁs SLíz, MarianN eds., Magyar névkutatás a 21. század elején. Budapest: Magyar Nyelvtudományi Társaság; ELTE Magyar Nyelvtudományi és Finnugor Intézet. 93-114.

SLíz, MARIANN in press. A személynevekkel kapcsolatos névtani és jogi terminológia [Onomastic and Legal Terminology Connected to Personal Names]. In press.

SMith, ElSDON COLES 1967. Treasury of Name Lore. Sketches and Observations on the Names We Bear. New York; Evanston; London: Harper \& Row. 
SVOBOda, JAN - ŠMilauer, Vladimír - OlivovÁ-NezBEdovÁ, LibuŠE - Oliva, KAREL - WitKowSKI, THEODOLIUS 1973. Základní soustava a terminologie slovanské onomastiky. Grundsystem und Terminologie der slawischen Onomastik. Zpravodaj Mistopisné komise ČSAV 14: 1-280.

SzENTGYÖRGYI, RUdOLF 2016. A Tihanyi alapítólevél személynevei III. Személynevek és helynevek kapcsolata [Personal Names in the Foundation Deed of Tihany Abbey. Part III. Relations between Personal Names and Place Names]. Névtani Értesitö 38: 9-18.

T. SOMOGYI, Magda 2015. Az írói névadás vizsgálata [Literary Onomastics]. In: FARKAS, TAMÁs - Slíz, MarianN eds., Magyar névkutatás a 21. század elején. Budapest: Magyar Nyelvtudományi Társaság; ELTE Magyar Nyelvtudományi és Finnugor Intézet. 207-226.

TAKÁCS, JUDIT in press. Finn-magyar kontrasztív névtani (terminológiai) vizsgálatok a személynévtípusok megnevezésének köréből [Finnish-Hungarian Contrastive Onomastic (Terminological) Analyses Concerning Terms for Types of Personal Names]. In press.

TóTH, LÁszló 2015. Alapfogalmak az irodalmi onomasztikában [Basic Concepts in Literary Onomastics]. Acta Academiae Agriensis Sectio Linguistica Hungarica 42: 203-215.

Tóth, VALÉRIA 2005. The Changes of the Hungarian Settlement Names. In: MATICSÁK, SÁNDOR ed., Settlement Names in the Uralian Languages. Onomastica Uralica 3. Debrecen; Helsinki: n.p. 135-153.

TÓTH, VALÉRIA 2008. Településnevek változástipológiája [Typology of Settlement Name Changes]. A Magyar Névarchívum Kiadványai 14. Debrecen: Debreceni Egyetem Magyar Nyelvtudományi Tanszéke.

UdVARI, ISTVÁN 1981. Н. В. Подольская: Словарь русской ономастической терминологии. [(Review.)] Névtani Értesítö 6: 71-3.

VÁCZINÉ TAKÁCs, EdIT 2016. Az írói névadás sajátosságai Karinthy Frigyes müvei alapján bemutatva [Specificities of Writers' Name Giving as Reflected in the Works of Frigyes Karinthy]. $\mathrm{PhD}$ thesis defended at Eötvös Loránd University, Budapest. Manuscript. https://doi.org/10.15476/ ELTE.2016.147

VÁRNAI, JUDIT SZILVIA 2005. Bárhogy nevezzük... A tulajdonnév a nyelvben és a nyelvészetben [Whatever the Name is ... Proper Names in the Language and in Linguistics]. Segédkönyvek a nyelvészet tanulmányozásához 42. Budapest: Tinta Könyvkiadó.

VÁRNAI, JUDIT SZILVIA ed. n.d. Angol-magyar nyelvészeti glosszárium / English-Hungarian glossary of linguistical terms. http://mnytud.arts.klte.hu/glosseng.htm \& http://mnytud.arts.klte.hu/ glossary.htm

Vasileva, Natalia 2014. Koordinierung der onomastischen Terminologie: die Suche nach der lexikographischen Lösung. In: TorT I DonadA, JoAN - MonTAgut I MontAgut, MonTSERRAT eds., Els noms en la vida quotidiana. Actes del XXIV Congrés Internacional d'ICOS sobre Ciències Onomàstiques. / Names in daily life. Proceedings of the XXIV ICOS International Congress of Onomastic Sciences. Biblioteca Tècnica De Política Lingüística 11. Barcelona: Generalitat de Catalunya. 99-106. http://www.gencat.cat/llengua/BTPL/ICOS2011/013.pdf \& https://doi.org/10.2436/15.8040.01.13

VINCZE, LÁSZLÓ 2004. A magyar belterületi helynevek kutatásában elért eddigi eredmények és további feladatok (A hazai és külföldi teljesítmények összevetése) [Achievements and Further Tasks in the Research of Hungarian Names for Inhabited Places. (A Comparison of the Hungarian and Foreign Achievements)]. In: FARKAS, FERENC ed., Magyar névtani kutatások itthon és határainkon túl. Névtani tanácskozás Jászberényben. 2003. október 17-18. Budapest: Magyar Nyelvtudományi Társaság; Szent István Egyetem Jászberényi Főiskolai Kar; TIT Jászsági Szervezete; Jászok Egyesülete. 187-191. 
VÖRÖS, FERENC 2009. Névváltoztatás és névhelyreállítás a kisebbségi magyar névhasználat tükrében: terminológiai javaslat egy névtani jelenség megnevezésére [Name Change and Name Reconstruction in the Name Use of Hungarian Minorities: Terminological Proposal for Identifying an Onomastic Phenomenon]. In: FARKAS, TAMÁs - KozMA, IsTVÁN eds., A családnév-változtatások történetei időben, térben, társadalomban. Budapest: Gondolat Kiadó; Magyar Nyelvtudományi Társaság. 57-74.

WALTHER, HANS 1998. Namenkunde und geschichtliche Landeskunde 2. Erläuterung namenkundlicher Fachbegriffe. Leipzig: Institut für Slavistik, Universität Leipzig.

WitKowski, TeOdolius 1964. Grundbegriffe der Namenkunde. Berlin: Akademie Verlag.

Witkowski, TeOdolius 1995. Probleme der Terminologie. In: Eichler, ERnst et al. eds., Namenforschung / Name Studies / Les noms propres. Ein internationales Handbuch zur Onomastik / An International Handbook of Onomastics / Manuel international d'onomastique. Handbücher zur Sprach- und Kommunikationswissenschaft 11. Berlin; New York: Walter de Gruyter. 1: 288-294.

TAMÁS FARKAS

ORCID: 0000-0002-7732-2302

ELTE Eötvös Loránd University Institute of Hungarian Linguistics and Finno-Ugric Studies Budapest, Hungary 